\title{
A heterogén glikoproteinszerkezetek biológiai szerepe
}

\author{
Jakab Lajos dr. \\ Semmelweis Egyetem, Általános Orvostudományi Kar, \\ III. Belgyógyászati Klinika, Budapest
}

\begin{abstract}
A fehérjemolekulához kovalens kötéssel kötődő szénhidrát-molekulák glikoproteineket alkotnak. A fehérjelánchoz különböző mennyiségű és összetételû szénhidrát-molekulák kapcsolódhatnak változó sorrendben és mennyiségben. $\mathrm{Ha}$ a fehérjemaghoz kötötten acidikus uronsavat, $\mathrm{SO}_{4}$-gyököt lehet találni, akkor proteoglikánokról vagy kevésbé helyesen glükózaminoglikánokról szólunk. Az élővilágban fellelhetők polimannanszerkezetek. A glikoproteinek acidikus uronsav vagy szulfatált glikózaminoglikánokat csak kivételszerúen tartalmaznak. Mind a szöveti, sejtes és mátrixszerkezetek, mind a humán „szérumfehérjék” valójában döntően glikoproteinek. A glikoprotein fogalom használata a klinikai orvostudományban máig is csak nagyon gyéren fordul elő, pedig a nem adekvát szófogalom-használat nemcsak nem helyénvaló, hanem egyúttal szemléletbeli zavarral is járhat. A közlemény ezt a gyakorlatot kívánja javítani, figyelembe véve, hogy ma már a „glikobiológia” szinte önálló tudományágként funkcionál. A szerkezeti sajátosságok összesítése mellett a közlemény ennek fontos, gyakorlati következményeit kívánja pótolni, funkcionális és konkrét klinikai vonatkozásait összefoglalni. Így kerül sor a glikoproteinek szerkezeti és biológiai tulajdonságainak bemutatására, hangsúlyt helyezve a klinikai fontosságra. A közlemény kiemeli a kóros struktúra és funkció klinikai vonatkozásait. Az orozomukoidot és a szérum-immunoglobulinokat a szerző külön fejezetben tárgyalja. Orv. Hetil., 2016, 157(30), 1185-1192.
\end{abstract}

Kulcsszavak: protein, glikoprotein, szerkezet, funkció, klinikai jelentőség

\section{Biological role of heterogeneous glycoprotein structures}

Carbohydrate molecules connected mostly with covalent junctions to protein chains are called glycoproteins. These carbohydrate molecules are attached to the protein core in different qualities and order. When the protein core is connected with acidic components such as uronic acid or $\mathrm{SO}_{4}$ radicals, they are called proteoglycans. The currently used name "glycosaminoglycan" in this case is not entirely correct. In the living world polymannane structures occur, too. Glycoproteins do not only exceptionally hold acidic groups but they have neuraminic acid derivatives. Tissue, cellular and matrix structures, and mostly all serum "proteins" are mainly glycoproteins. In the everyday clinical practice glycoproteins are mentioned as proteins. Nevertheless, the inadequate use of the concept may cause errors in the attitudes, too. This paper aims to correct this notion, because the term of "glycobiology" has already been expanded to be an independent scientific field. The practical clinical consequences of recent knowledge in this field are also summarized including novel findings on glycoprotein structures and functions. The importance of the quantity of carbohydrates, and their structural arrangements are also presented. In short, significance of glycoproteincarbohydrate structures, as well as their physiological and pathological roles are reviewed in order to introduce the field of "glycobiology". Orosomucoid and immunoglobulins are discussed separately.

Keywords: protein, glycoproteins, structures, biological roles, clinical significance

Jakab, L. [Biological role of heterogeneous glycoprotein structures]. Orv. Hetil., 2016, 157(30), 1185-1192.

(Beérkezett: 2016. február 24.; elfogadva: 2016. április 9.) 


\section{Rövidítések}

$\mathrm{ALR}=\mathrm{AIM}$-like receptor; $\mathrm{APR}=$ acute phase reactant; $\mathrm{At}=$ antitest; CTL $=$ C-type lectin; CTLR = C-type lectin receptor; DS = dendritikus sejt; GP = glikoprotein; ICAM = intracelluláris adhéziós molekula; Ig = immunglobulin; LPS = lipopoliszacharid; LRR = leucin-rich repeat; $\mathrm{Ma}=$ macrophag; $\mathrm{MBL}=$ mannose-binding lectin; Mo = monocyta $;$ orozom. = orozomukoid; OS = oligoszacharid; PAMP = pathogen associated molecular pattern; PCP = polyarthritis chronica progressiva; $\mathrm{PRR}=$ mintázatfelismerô receptorok; szh = szénhidrát; $\mathrm{TLR}=$ Toll-like receptor

Az élő szervezet építőanyagai a fehérjék, szénhidrátok és lipidek. Valójában azonban ezek a molekulák, vegyületek egymással, egymás alkotórészeivel összekapcsolódva heterogén molekuláris szerkezetek formájában építik fel az élő organizmus minden szövetféleségét, szervét. Szöveti típusok szerint az egyik vagy másik molekuláris struktúra dominánssá válik. A mindennapi orvosi gyakorlatban egy-egy orgánum „anyagát”, sejtes felépítését fehérjének tituláljuk leegyszerúsítve. A vérszövet szerkezete a fluidum mellett alakos, sejtes elemekből, plazmafehérjeösszetevőkből áll. Ismert azonban, hogy a plazmafehérjék döntő részben glikoproteinek (GP), és az alakos elemek szintén összetett, komplex struktúrák. A fehérjeés szénhidrát- (szh-) kompozíciók a már említett GP-k, a szh + lipid molekulák alkotta glikolipidek vagy gyakran glikolipoproteinek. Ez utóbbiak leegyszerúsített lipoprotein meghatározást birtokolnak. Összesítve tehát azt mondhatjuk, hogy a szervezetben előforduló, meghatározó struktúrák két fó típusa a GP és a glikózaminoglikánokat tartalmazó proteoglikán. Ez utóbbiak legnagyobbrészt $\mathrm{SO}_{4}$-gyököket hordoznak. A lipidek hasonló módon fehérjék és szh-alkatrészek tartalmazói is. A lektinek, köztük például az I-es típusú lektinek oldott állapotban, mátrixba beépülve vagy sejthez, sejtmembránhoz tapadva felismerő, kapcsolatteremtő szerkezeteket tartalmazó struktúrák [1-5].

\section{A glikoproteinszerkezetek felépítése, funkciója}

A fehérjék ko- és poszttranszlációs módosulása a glikoziláció, ami a humán szervezetben a leggyakoribb összetételbeli alteráció. Ez a szervezeten belül olyan arányú módosulat, ami 70-90\%-ot is kitesz. Egyes sejtekben, mikrobákban egyedileg sajátos glikokonjugátumok formájában lelhető fel és individuális tulajdonságokkal rendelkezik. Az oligoszacharid (OS seu glycan) molekulák elrendeződése a struktúrán belül meghatározott, sajátos. A sejt- vagy makromolekula-felszíneken az elrendeződés egyedi, ami az alapja a szenzorok és a biokémiai szignálok keletkezésének, továbbításának. Az szh-k biodiverzitása sokkal nagyobb, mint a proteineké, alkalmasak az szh „kód” szerepkörére. Az érintett 20 szh-molekula a természetben több mint negyvenféleképpen csatolódhat a fehérjéhez, alkothat egyedi, molekuláris karaktert, GPmolekulát. Az eukaryocytákban az N-kötött glikoziláció mellett az X-PS/T kapcsolódás a leggyakoribb. A polimannan a harmadik lehetséges kötésforma. Az előbbi az úgynevezett O-glikozid kötéstípus. Az így felépülő szhtartalmú molekulák neutrális vagy negatív elektromos töltésűek, szemben a mindig acidikus töltésú, leggyakrabban $\mathrm{SO}_{4}$-gyököket tartalmazó proteoglikánokkal [69]. A neutrális GP-k tartalmazhatnak glükóz, galaktóz, mannóz, fruktóz, glükózamin, galaktózamin mellett neuraminsav-származékot. A neuraminsav mannózamin és piroszőlősav kondenzációs terméke. Acetil-, diacetil-, ritkán metilgyököt tartalmaz, hogy sziálsavvá változzék. Ez nemcsak abban különbözik a többi szh-molekulától, hogy elektronegatív töltésü, hanem abban is, hogy ha jelen van a GP-molekulában, akkor mindig láncvégi pozíciót foglal el és sajátos funkcionális tulajdonságokat kölcsönöz a molekulának [10-13].

A legismertebb, legkorábban feltárt OS-szerkezetek a vércsoportantigének, amelyeket hemagglutininek (lektinek) ismernek fel (lego, legere, lēgi, lectum = olvas, leolvas). A vércsoportantigének a legismertebb membránGP-k, egyúttal az immuntolerancia eleven tanúi. A Lewis-féle epitopok a legegyszerúbb OS-csoportok közé sorolhatók (N-acetil-glukozamin + galaktóz + fukóz). Az egy molekulával történő kiegészülés Lewis-X-nek jelölt szerkezetet eredményez. Ez több biológiailag fontos molekulában tűnik elő. Sziálsavkötődés sialyl-Lewis-Xcsoportot eredményez. Ha az OS-csoportból a sziálsav és galaktóz hiányzik, akkor olyan autoantitest keletkezhet, ami N-acetil-glukozamint ismer fel. Ez előfordul például autoimmun genezisű folyamatokban, mint polyarthritis chronica progressivában (PCP), psoriasisban és domináns epitopként Streptococcusok OS-csoportjában. Ez keresztreakciót mutat az $\mathrm{N}$-acetil-glukozaminnal, miozinnal, tropomiozinnal és vimentinnel. Felismerő, kötő molekulája kollektinekkel, valamint $\alpha \mathrm{M}$-alegységgel jellemezhető $\alpha \mathrm{M} \beta 2$ integrinnel köthető össze. Ez utóbbi thrombocytamembrán-változást eredményez. A terminális mannóz általában OS-ben szolgálhat szenzorként és kötődhet például mannose-binding lectinhez (MBL). Hasonló jelenség fordulhat elő például dendritikus sejtek (DS), monocyták (Mo), macrophagok (Ma) esetében (C-type lectins). Toll-like receptorok esetében hasonló a helyzet. Az OS összetételbeli változás a "kórokozó” proteinlánc saját maga elleni, az idegen és saját molekulával szembeni antitest- (At-) képződést generálhat. A pathogen associated molecular pattern (PAMP) az idegen és patogén szerkezetek felismerését teszi lehetővé. A C-type lektinek (CTL) molekulárismintázat-módosulást hasonló módon ismerik fel. A CTL-ek közé több molekulárismintázat-felismert szerkezet tartozik (például dectin-CTLl, langerin és mások). A PTX3, SAP, CRP kapcsolódási helyei igen szélesek. Kötődhet membránszerkezetekhez. Ig például LPS-hez, galaktomannanhoz. További lehetőségek citokinek, growth faktorok, alapállomány-komponensek (kondroi- 
tin $\mathrm{SO}_{4}$-ok, hialuronsav, fibronektin, versican, aggrekán, szindekán, perlekán, dekorin, kollagén IV típus, heparin) [13-16].

A sialic acid-binding Ig szuperfamíliába tartoznak a Siglec-s. A DS-membránon és más szerkezetekben találhatók. A CTL-ek például szelektineket, adhéziós molekulákat ismernek fel Lewis-X-csoportok birtoklása révén [17-20]. Az L-szelektin (endothelin sejtek Weibel-Palade-testekben), a P-szelektinek (a thrombocyta- $\alpha$ granulumokban) és E-szelektinek terminálisan elhelyezkedő epitopokat (többféle glikoform előfordul) ismernek fel, különítenek el [21-23]. Az E-szelektinek az endotheliumban termelődnek és a Weibel-Palade-testekben tárolódnak. A galektinek $\mathrm{Ca}^{++}$-dependens módon a galaktózt ismerik fel. A különböző sejtek membránján (Mo, Ma, DS) kollektinfamília-tagok által felismert molekula lehet mannóz, ami előfordulhat polimannóz alakban is. Az N- és O-glikánok jellemző módon sziálsavat hordozhatnak. A C-típusú, aszialo-GP-ket felismerő Reket hepatocyták és Kupffer-sejtek membránja hordozzák. A megkötött molekulák sorsa az endocytosis, kivonásuk a keringésből. A Gram-pozitív baktériumok felszínén peptidoglikánréteg található, míg a Gram-negatívok membránján lipopoliszacharid (LPS) antigének helyezkednek el. Az LPS lipid A + OS + O antigén fó alkotórészek alkotta R-komplex. Kiderült azonban, hogy az érett, múködő alakzat több más alkotórészt is magában foglal. Előbb a TLR - ami maga is GP-szerkezet kötődik, majd az LPS-kötő fehérje és az MD2 ( $\beta$-cupfolded protein) és a CDl4 a csatlakozó alakzat, hogy készen álljon a hatékony multi-R-komplex [24].

A D-, T- és B-sejt-felszín-szerkezetek felismerését szolgálják a SIGN-ek (típus I. transzmembrán molekulák, ICAM-3-grabbing non integrin = CD209), az intracelluláris és membránadhéziós molekulák. Az ICAM (intracelluláris adhéziós molekula) erősen glikozilált T-ly-kban. A dectin-1 csak $\beta$-glukánokat ismer fel. Együttmúködik a Toll-féle R-ekkel. A TLR legalább 10 típusa immunocyták és hámsejtek membránján elhelyezkedve a mikroorganizmusok felismerésének a letéteményesei. Fontosak a természetes és szerzett immunitás összerendezésében. Dectinrokonok a CTL-tag langerin és egyéb molekulák között integrinek is fellelhetők (1. táblázat) [25-28].

Mint már említést nyert, PCP-ben a reumafaktorok vagy más autoimmun folyamatokban is (például sclerosis multiplex) a megváltozott saját szerkezet kiváltotta védekezőreakció zajlik. Ezekben az esetekben az alap az OSmódosulás. A jelenség infekcióban (például tbc) vagy graviditásban is előfordul, immuntolerancia kialakulásával egyetemben. Ezt a jelenséget lehet felismerni a tireotrop hormon R-struktúra-módosulása kapcsán. Ép szerkezetek esetén természetesen nem képződnek auto-At-k, de a szabaddá vált szerkezeti elemek (darabok), alegység ellen igen, és jellemző tünetegyüttest, szindrómát eredményezhetnek (Basedow-Graves-szindróma). Ebben az esetben a Ma mannóz R-hez kötődik az az A alegység,
1. táblázat | LPS multireceptor-komplexus, TLR 1-10, LPS-kötő fehérje, CD14, MD2 ( $\beta$-cupfolded protein) ligandumok

1. Proteoglikánok (heparin-S, biglikán, hialuronsav)

2. Hialuronan

3 . Inter- $\alpha$-inhibitor

4. Surfactant protein A

5. HSP 60 és HSP $60 / 70$

6. Fibrinogén (hasítási termékek)

7. $\beta$-defenzinek

8. Oxidált LDL

9. Minimálisan módosult LDL

10. Fibronektin (hasadási termék)

11. High mobility group protein $\mathrm{B}$

12. PAPC (palmintoil-arachidonoyl glycero-phosphorylcholin) derivátum foszforil-cholin

13. Mikroorganizmus-extraktumok

14. Fetuin A ( $\alpha 2$ HS-GP)

amely auto-At-képződést indukál. Mind a TSH, mind az R GP-struktúrák. A megváltozott langerin következménye például a Birbeck-granulum-képződésben mutatkozhat meg Ag-keresztprezentáció révén. A ligandum pedig mannóz-, glukozamin-, N-acetil-származék és 6 Lewis-X-kombináció [29-32].

\section{Az orozomukoid}

Egyedi sajátossága módot nyújtott a GP-szerkezetek öszszetételének, hatástani, klinikai szerepének a vizsgálatára. Mégis azt kell mondani, hogy a teljes klinikai értékelhetőség még hosszadalmas feltáró tevékenységet igényel. $\mathrm{Az}$ élettani molekula szerkezeti ismerete birtokában is sok még az ismeretlen összefüggés. A birtokunkban levő ismeretanyag már lehetőséget nyújt a szerkezet és funkció összefüggéseinek átlátásához, megközelítéséhez. A molekula erősen elektronegatív töltésư. OS-tartalma $45 \%$. Úgy tűnt, hogy a legnagyobb szh-tartalmú molekulával állunk szemben, de kiderült, hogy abban a galakto-GP 76\%-os szh-tartalmával megelőzi. Régebben tudott, hogy karakterisztikus acut phasis reactansról (APR) van szó. A szervezeti elhárító válaszban (inflammatio) plazmabeli koncentrációja hamar meredeken megemelkedik. Immunmoduláns, inflammatiogátló tulajdonsága különböző kémiai szerkezetek kötőképességével társul. A lipokalinfamília tagja. Élettani viszonyok között plazmabeli koncentrációja stabil, $80-90 \mathrm{mg} / \mathrm{dl}$ egészséges felnőttekben. A molekuláris tömeg $4 \mathrm{l}-43 \mathrm{kD}$. Egy molekula 5 komplex típusú N-kötött glikánt tartalmaz. Oldékonysága feltűnően nagy. A peptidlánc 183 aminosavat tartalmaz. Az orozomukoid (orozom.) I-es és II-es fó típusa különíthető el. Polimorfizmus jellemzi. Homológia észlelhető a humán IgG OS-ek, az endothelium növekedési faktor és orozom. között. Az N-kötött OS- 
láncok meghatározott rendben kapcsolódnak a polipeptid lánchoz, di-, tri- és tetraantennaris alakzatban. Ez a glikoform diverzitás alapja. A láncban terminális pozícióban a neuraminsav sziálsavszármazéka lelhető fel, ami az OS-tömeg 10-12\%-át teszi ki, az elektronnegativitás meghatározója. A két molekulatípus között 23 aminosav-különbség van. Emberben az 1-es típus domináns. Lektinekhez kapcsolódhat. Fukoz a másik molekula, amely a Nac-glukozaminhoz társul, az pedig a galaktózhoz. Érdekes, hogy a humán plazma orozom. 30\%-ában egyáltalán tartalmaz fukozt, ez pedig a glikánszerkezet diantennaris alakjának hiányával társul. A molekuláris szerkezet diverzifikációja $10^{5}$ glikoform létét eredményezi. A di-, tri- és tetraantennaris alakzatok elrendeződése szabályozott. A normális humán plazmaorozom. 12-20 glikoformot tartalmaz. Ezen mikroheterogenitás szorosan kapcsolódik a patológiás folyamathoz. A diantennaris forma gyakoribb a szervezeti APR-ben, továbbá összefügg a fukoz jelenlétével. A háttérben IL-1, TNF- $\alpha$ és glukokortikoidok munkálkodnak. Más folyamatokban is módosul a mikroheterogenitás és egyben a biológiai funkció. Alkoholos hepatopathia, vírushepatitis, valamint PCP esetében mutatkozik ez meg. A termelődés döntően a hepatocytákban történik, de bizonyos, hogy van extrahepaticus képződés is. A terminális sziálsav lehasadásával képződő szerkezet a hepaticus (hepatocyta, Kupffer-s.) asialo-GP-R-eken keresztül kikerül a keringésból és lebomlik (2. táblázat) [32-34].

Az orozom. emberben három szomszédos gén terméke. A produktumok közt körülbelül százszor több az orozomukoid-1, mint az orozomukoid-2. Az előfordulás igen széles körü, még az egysejtüekben is fellelhető. A nyálban előforduló orozom. mintegy 70\%-os homológiát mutat a humán szérumbeli rokonával. A szérumbeli orozom.-tartalom nagyobb részben extrahepaticus szöveti termék. A szervezetet ért minden károsodás, sérülés, a szervezetbe bejutott élő és élettelen matériával szembeni APR az elhárító válasz. Ez részben a nem specifikus, veleszületett védelmező folyamat, az inflammatio, részben specifikus, szerzett immunválasz, amelyek szoros összeköttetésben vannak egymással. A helyileg fellelhető történések mellett mindig általános, az egész szervezetet érintő változások is vannak. Az elhárító szervezeti választ a cortico-hypothalamus-mellékvese tengely szigorúan regulálja. Ennek fontos hányadát a keringésben észlelhető változások képezik. Jelentős összetevője a plazmafehérjék koncentrációjának a jelentős módosulása. Sok úgynevezett acut phasis reactanst (AP-reactanst) ismerünk, amelyek változásai különböző irányban, tempóban, mértékben történnek a vérben. Emelkedő koncentrációváltozás esetén pozitív, csökkenő esetben negatív reactansról beszélünk. A változások sokaságából kiemelhető a pozitív orozom. és a negatív albumin különlegesen összefüggő jellege. A drogkötésben ugyanis a plazmafehérje albumin, ami negatív reactans és az orozom., amely pozitív reactans, klinikumban fontos, jellegzetes helyzetet teremtenek. A kiváltó domináns citokinek alap-
2. táblázat $\mid$ Molekuláris mintázatot felismerő szerkezetek példái (lektinsze rü kapcsolódások)

\begin{tabular}{ll}
\hline 1. SAA & Mikroorganizmusok, azok összetevői \\
2. Clq & Mikroorganizmusok, Fc-Ig régió, \\
& $\begin{array}{l}\text { pentraxinok, EC mátrixalkatrészek } \\
\text { (laminin, fibronektin, fibromodulin, } \\
\text { oszteoadherin stb.) }\end{array}$
\end{tabular}

3. Rövid pentraxinok Mikroorganizmusok, EC

(CRP, SAP) mátrixalkatrészek, proteoglikánok, fibronektin, laminin, kollagén IV, módosult LDL, komplementkomponensek

4. Hosszú pentraxinok Mikroorganizmusok, mátrixalkatrészek (pentraxin-3) inter- $\alpha$-inhibitor, fibroblast-növekedési faktor, (kokomponensek: Clq, faktor $\mathrm{H}$ ) L-ficolin, apoptotikus sejtek

5. Kollektinek Szénhidrátstruktúrák, mikroorganizmusok (MBL, SP-A)

6. Properdin Mikroorganizmusok, kokomponensek, sejtek kötése, a felszíni PG-k GAG-láncai révén

7. Ficolinok Mikroorganizmusok, szénhidrátok

8. Lektinek (számuk $\uparrow$ ) Ag-At társulás, T-ly-, R-felismerés, dendritikus sejt asszociálta lektinek: dectinek stb., I-es típusú lektinek, Siglec-s (Se Ig-like lektinek 1-11), sialo-adhezin, CD22 (B-ly membránon), CD33, Siglec-s kizárólag sziálsav-felismerés, myelin, asszociált GP, galectin, MBL (mannózkötő lektin), szelektinek, ICAM, kadherin

9. Toll-like R-ek (1-10) Intracelluláris komponensek

ján beszélhetünk 1-es típusú (orozom., CRP, $\alpha$-anyloid-A, haptoglobin, hemopexin) tényezőkről. Ebben az IL-1, IL-6, TNF- $\alpha$, valamint a glukokortikoidok a meghatározó regulátorok. A II-es típusú AP-reactansok esetében döntő reguláris tényezők az IL-6 és az IL-6-rokon citokinek, valamint a kortikoidok. A negatív AP-reactansok között az albumin, transzferrin, az $\alpha 2 \mathrm{HS}-\mathrm{GP}$ említendők. Az AP-reactansok termelődési helye a máj, különösen élettani viszonyok között. Kóros körülmények között is a máj a legfőbb termelődési hely, de nagyobb szerep jut az extrahepaticus szöveteknek (haemopoeticus sejtek, Ma-k). Az orozom. jelenlétét különböző tumorszövetekben is kimutatták az $\alpha 2 \mathrm{M}$-mel együtt, míg tüdőtumorokban csak az orozom. jelenléte igazolódott. A növekedési hormon az orozom. negatív regulátora. Az endothelium és placentasejtek hasonlóan orozom.-termelők. Ép szövetben és T-, B-lymphocytákban nem kimutatható, monocytákban igen. Az elmondottak azt tanúsítják, hogy az orozom. antiinflammatorikus, immunmoduláns hatást gyakorol (anti-Neu-sejt, -komplement, -LPS indukálta citokintermelődés, thrombocytaaggregáció, kapilláris permeabilitás). Az immunmoduláns hatást a glikoziláció döntően módosítja. Az orozom.-termelődést az IL-1 $\beta$ sokkal erősebben befolyásolja, mint az IL-6. Mint már említettem, az APR-ben 
az orozom. jelentős glikozilációs módosulást mutat, fontos a sejtpolarizáció-változás. A drogkötésben fontos tényezők a temperatúra, a hidrofób mivolt. Az elektrosztatikus kapcsolódás, főként bázikus szubsztanciák esetén jelentős. A leggyengébb kötődést a szteroidok mutatják (a szintetikus formák is). Az a-sialo alak csökkent propranololkötést mutat, a progeszteronkötés nem változik. Lényeges tehát a bázikus jelleg a sztereoaktív találkozáshoz. Nem árt meggondolni az orozom.-glikoziláció rendkívüli változatosságát nemcsak kóros viszonyok között, hanem élettani helyzetben is. Az ösztradiol számára két kötőhely is rendelkezésre áll a molekulában $[35,36]$.

Az elmondottak alapján mégis meglepő, hogy az orozom. a drogok sorával tud társulni. Jelentős a kötési konstans változása. Elgondolkodtató, hogy egyedi kóros esetekben milyen jelentősége lehet a drogkötésnek. A szervezeti védekező-elhárító válaszban a plazma-orozom.-koncentráció akár az élettani érték 4-5-szörösére emelkedhet. E koncentráció- és szerkezetváltozás esetében hogyan változik meg a drogkötési kapacitás? Ugyanakkor az albuminkoncentráció jelentősen csökken. Jelentős lehetőség, különbség adódhat a drogkötésre a szérum versus szövet viszonylatban. A plazmadrog-koncentráció nagy változást mutathat a szöveti szinthez képest. Az említetteken túl pontosabb támpontként szolgálhatna a farmakon/nonfarmakon vegyületek kötődésváltozásának az ismerete. Itt említendő a vanilloidok, szerotonin, platelet activating factor, melatonin, $\operatorname{IgG}_{3}$, heparin, warfarin, tamoxifen, hisztamin, imatinib kötődésének, illetve a kötődési képességének az esetleges módosulása. A kötődési viszonyokban más kémiai szubsztanciák esetében is mutatkozhatnak eltérések. Az sLex epitop sziálsav komponense bizonyos esetekben nem tud kapcsolódni például L- és P-szelektinekkel. Módosul a kötődési lehetőség a bi- és triantennaris glikáncsoportok esetében. A deszializáció csökkenti a progeszteron-propranolol kötődést. Hidrogénionok jelenléte módosíthatja az orozom.- és sLex-kapcsolódást P-szelektinnel. Ez utóbbi folyamatot a $\mathrm{Ca}^{++}$jelenléte igényli.

A szerkezet originális glikozilációja a polipeptid lánc és az egész struktúra stabilitását biztosítja. Eltérő módszerekkel igazolható volt ilyen hatás IgM, fibronektin-, hemagglutininmolekulák esetében. Ismerve a glikoformok sokaságát, még sok további adat kerülhet felszínre.

A mintázatfelismerő receptorok (PRR) sokaságának, a lektineknek különböző csoportosítása lehetséges. Egyik lehetséges besorolás szerint a C-type lectin receptorok (CTLR), a Toll-like-féle receptorok (TLR), a NOD-like vagy nucleotide-binding, domain, leucin-rich repeat (LRR) containing receptorok (NLR), a RIGl like receptors $(\mathrm{R}=$ retinoic acid), valamint a megtévesztő jelölést kapott AIM2-like receptors (ALR) (absent in melanoma) különíthető el. Elhelyezkedésük igen változatos. Lehet intracelluláris, sejtmembrán és szekréciós alak. Az intracelluláris lokalizáció is változó. Számuk szinte napról napra változhat. Összekapcsolódásuk szinte minden szérum-GP-vel lehetséges [37-41].

\section{A humán immunglobulinok glikozilációjáról}

A humán immunglobulinok (Ig-k) mind tartalmaznak OS-csoportokat. Ezek mennyisége széles határok között mozoghat. A leggazdagabbak OS-tartalom tekintetében az IgA, IgM, IgE, IgD. A glikánok mindig a nehézláncon találhatók. A variábilis régióban is előfordulnak. A kappa- és lambda-könnyúláncok nem hordoznak konzervált OS-locust. A glikánok kovalens kötéssel, az As/X és Ser/Threon csoportokhoz kapcsolódhatnak (N-glikozid- és O-glikozid-kötés). Az IgG-molekula a legszegényebb OS-ekben. Az IgG N-glikozid-kötésben akár 32 OS-típust tartalmazhat sokféle variációban. A variációk kóros folyamatokban változnak. A glikánláncok hoszsza, összetétele változik, és így alkalmas lesz például mannan-binding lectin (MBL) kötésére. Az eloszlás biés triantennaris, és sokféle glikoform keletkezhet. Az OS-csoportok leginkább a lánc stabilitását biztosítják, továbbá más struktúrák felismerésében múködnek közre. Igen fontos például a már említett lektinkötődés. Továbbá a konformáció módosulásában, az intracelluláris transzportban, szekrécióban, a stabilitás módosításában szerepelnek. Biztosítják az adekvát effektív hatásokat, az optimális Fc-Fab találkozást. A glikán mennyisége 35\%, a Glu-Nac 14\% G1 és G2 típusú glikán. Ezeknek a csoportoknak a 30\%-ában Glu-Nac-t hordoznak és 70\%-ban fukoznegatívok [10, 34, 42].

Az IgA két alosztályra oszlik, két konzervált N-kötő hellyel, mindkét $\alpha$-láncon, amely tartalmaz 2 vagy 3 glikozilációs helyet (N-kötött). Jellemző az IgA-ra a szekrétumokban (például colostrum), a mucosalis felszíneken való jelenlét. Az IgAl a domináns forma, jellemzően monomer alakban, de dimer és polimer formában is előfordul. A galaktóz végződésú glikánok ligandumai az asialo-GP-receptoroknak. A plazma-IgA 30\%-a tartalmaz N-kötésben glikánokat. Az IgA szekretált alakja, a szekretor komponens és J-láncok erősen glikoziláltak. A 16 kD-os, glikolizált J-lánc az IgM-pentamerben hasonlóan előfordul. A szekretoros komponens O-kötött glikánok hidroxilgyökök közbejöttével szerinhez vagy threoninhoz tapadnak. Az IgA-molekulához csatolt OS változó, de jelentős tömegü (például $8 \mathrm{kD}$ ) egységekben lelhető fel. A láncszerkezetek nagyon változatosak. Az elrendeződés itt is bi- és tetraantennaris, és sokféle glikoform fellelhető. A szekretoros komponens az epitheliumfelszíneken fellelhető polimer IgA R-ekből ered. A gastroinestinalis respiratorikus rendszer, a tej, könny, nyál, nyák a főbb előfordulási helyek. A teljes glikántömeg 50\%-ában Glu-Nac terminális, míg körülbelül 12\%ában oligomannóz glikánalakzat. A szekretoros IgA O-glikán alakban megköt mikroorganizmusokat, gátolva azok megtapadását és siettetve az eltávolítást. A J-láncok OS-csoportjai több mint 75\%-ban tartalmaznak sziálsavat. Az IgA szekretoros csoport $\mathrm{N}$-glikánja révén köt meg mikroorganizmusokat. A szekretoros komponens 7 OS-kötő helyet hordoz. Ezek a csoportok tartalmaznak 
LeX- és sLex-gyököket, amelyek fontos lektinfelismerő helyek, továbbá lektinek által felismerhető kötő- és adhéziós, kis OS-csoportokat.

Az IgM-láncon $5 \mathrm{~N}$-kötött glikozilációs hely fordul elő. Az IgM-pentamer összesen 30 N-kötött glikánt tartalmazhat. A szérum-IgM 20\%-a nagy arányban ( 20\%) Glu-Nac végződésű szerkezet. Aggregátumképződés esetében csatlakozhat mannózhoz. Az IgM komplett glikánszerkezete lehetővé teszi mikroorganizmusok agglutinációját. A sziálsav-végződésű IgM kötőhelyet biztosít a vírus lektin-hemagglutin számára és lehetővé válik az influenzavírus agglutinációja. A J-lánc egy $\mathrm{N}$-típusú glikozilációs helyet birtokol, főként biantennaris, szializált glikánt, fukoz nélkül. Az influenzavírus másik antigénje a neuraminidáz is GP-szerkezet. A variábilis régióglikoziláció módosítani tudja az Ag-kötést. Kóros folyamatokban, például plazmasejt-dyscrasióban leírtak $\lambda$ - (lambda-) lánc-glikozilációt. Follicularis lymphomában a variábilis régióglikánok egy vagy több OS-csoportot az Ag-kötő helyen belül tartalmaznak. Az Fc és FcR-ek öszszeköttetést létesítenek a specifikus (szerzett) celluláris és humorális válasz és a veleszületett, naturális immunválasz között.

Az IgD O-glikánok mono- vagy diszializált struktúrák. Szerepük van a szerkezeti rigiditás szabályozásában, a kapocsrégió kifeszítésében. E a sajátosság az Ag hatékony megkötését segíti elő a BCR-komplex partikulumjaként. A glikánkötés a CD4 és CD8 T-lymphocytákon

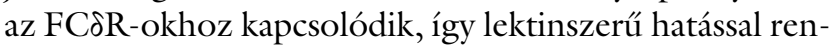
delkezik. Antitestkötődés a glikán lehasadása után nincs. A monoszacharid kompetitív módon gátol.

$\mathrm{Az}$ IgE-molekula egészen egyedi tulajdonságokkal büszkélkedhet. Szérumkoncentrációja igen kicsi, a biológiai aktivitása igen nagy. FCR-hez erős affinitással tud kapcsolódni. Az FCRl mastocyták, bazofil sejtek membránján találhatók. Az FCR2-k kis affinitással, T-, B-, Eosejteken helyezkednek el, és az R erősen glikozilált. Olyan IgE-kötő helyeket hordoznak, amelyek jelentős affinitást mutatnak az szh-kötő régiókkal, a C típusú lektinszerű kötőhelyekkel [43-45].

\section{Következtetések}

A GP fogalom csaknem teljes „kifelejtése” az orvosi terminológiából azt eredményezi, hogy az indokolt élettani, patológiai, klinikai használata kevéssé érvényesül a mindennapokban. Pedig most már az ismeretanyag konkrét klinikai alkalmazására is lehetőség nyílna. Ma már szinte önálló elméleti-gyakorlati tudományterületté fejlődött, és „glikobiológia” megjelöléssel önálló tudományággá nőtte ki magát. Az elmaradás jelentős hiánypótlása előrehaladást jelentene. Alkalmazásuk szükségszerűségére a klinikumban konkrét eredményekre hívják fel a figyelmet.

Az IgA-glikánok módosítják az FcaR-hoz való kötődés affinitását. Az IgA-molekula kapcsolódik a CD4és CD3-lymphocytákhoz, Nac-glükózamin-végződésü
N-glikánokhoz. Az IgA, amely jelentős mennyiségú glikánt hordoz, eredményes esetben tapad az R-hez, mutat endocytosist, megelőzve a neutrális OS-csoportokat hordozó glikánokat. Kóros szerkezetű Ig-kkel találkozhatunk, mint már említettem, több patológiás folyamatban.

Csökken az aberráns glikoziláció IgA-kiválasztása a vesében. A májban az asialo-GP-R nemcsak sziálsavhiányos, hanem a galaktózhiányos OS-csoportokat sem ismerik fel, nem kötik meg. Maradnak a keringésben és a kóros Ag-IgAl immunkomplexusok tovább maradnak a vérben. Fokozódik az immunkomplexus-retenció. Mindez elősegíti a lerakódást a vérben, a mesangiumban. A variábilis régió is tartalmaz OS-eket, felszaporodik a polimer szerkezet, növekszik az aggregáció. Fokozott lesz a komplementrendszer aktivációja. Mindezek fokozatos renalis funkciózavarhoz és végül veseelégtelenséghez vezetnek. Szembetűnő az IgA-depozíció a mesangiumban. Kóros glikánszerkezetű Ig-kkel találkozunk, mint már említettük, több patológiás folyamatban. PCPben nagy arányban fordulnak elő olyan sziálsav- és galaktózmentes OS-csoportok az IgG-kben, amelyek jelentős szaporulatot mutathatnak a szérumban. Ezek pozitív korrelációt mutatnak a betegség stádiumával, súlyossági fokával. Ez a kóros alakzat lecsökken a klinikai remisszió végéig. Koncentrációjuk párhuzamosságot mutat a betegség aktivitásával. Ezeknek a glikoform mennyisége jelentősen csökken graviditásban, enteritis regionalisban, fiatalkori PCP-ben, LED-ben, Sjögren-szindrómában, tbc-ben hasonló jellegű változások figyelhetők meg. Ignehézlánc-betegségben, valamint PCP-ben a domináns IgG teljes mértékben agalaktozilált biantennaris glikánt birtokolhat és összefüggést mutat a betegség aktivitásával. Az agalaktozil IgG a synoviumban deponálódik. A mannankötő lektin fellelhetősége, mennyisége összekapcsolódni látszik a késői kezdetű, gyors lefolyású formával. A variábilis végü is tartalmazhat OS-eket és növekszik a polimer alakzat, a komplementaktiváció. Ilyen esetekben a mannózkötő lektinek által felismerhető terminális galaktóz és Glu-Nac végződés tovább növekedhet más patológiás állapotokban is. Felmerül továbbá egyes kórfolyamatokban hibás glikánalakzatok, enzimek, nukleotid donorok jelenléte, de a fehérjelánc kóros elváltozása is. Egészségesekben ilyen jelenségek nem fordulnak elö. Follicularis lymphomában fokozatosan felszaporodott glikozilációs helyek tünhetnek fel az Ig-kben. Hasonlóan kóros glikoformokkal találkozunk Burkittszindrómában, diffúz, nagy B-sejtes lymphomában [4650].

Érdemes itt megemlíteni, hogy egészséges humán szérumban az Ig-Gp-k mennyisége a szérum-GP felét teszi ki. A komplementkomponensek, az összes Ig, a natív, veleszületett és adaptív immunitás specifikus molekulái néhány kivétellel mind-mind GP-k. Érdekes, kivételes jelenség, hogy a szérum-GP-k poliszacharidokat, glikózaminoglikánokat nem tartalmaznak. Egyetlen kivétel azért akad. Az inter- $\alpha$-inhibitor (és pre- $\alpha$-inhibitor) két 
nehéz- és egy könnyúláncot (bikunin) tartalmaz, amely kondroitin $\mathrm{SO}_{4}$-ot is hordoz és szövetekben hialuronsavat köt meg $[44,47]$.

Összesítve tehát elmondható, hogy a GP-szerkezetek legfőbb funkciói a molekuláris alakzatok, a stabilitás kontrollja, a felismerési folyamatok, a polipeptid szerkezet regulációja, a sokirányú interakció biztosítása területén találhatók. A szövetek felépítésének tökéletessége vonatkozásában hasonlóan elengedhetetlenek. Röviden az élettani funkció úgy foglalható össze: az szh-k funkciója a különböző sejtek mobilizációjának biztosítása, a sejtmembránok receptorai szignalizációjának összehangolása és a sejtapoptózis irányítása.

Anyagi támogatás: A közlemény megírása anyagi támogatásban nem részesült.

A szerző a cikk végleges változatát elolvasta és jóváhagyta.

Érdekeltségek: A szerzőnek nincsenek érdekeltségei.

\section{Irodalom}

[1] Moshage, H.: Cytokines and the hepatic acute phase response. J. Pathol., 1997, 181(3), 257-266.

[2] Zopf, D., Roth, S.: Oligosaccharide anti-infective agents. Lancet, 1996, 347(9007), 1017-1021.

[3] Pepys, M. B., Hirschfield, G. M.: C-reactive protein: a critical update. J. Clin. Invest., 2003, $111(12), 1805-1812$.

[4] Hernández-Mir, H. G., Helin, J., Skarp, K. P., et al.: Glycoforms of human endothelial CD34 that bind L-selectin carry sulfated sialyl Lewis x capped O- and N-glycans. Blood, 2009, 114(3), 733-741.

[5] Jones, A. L., Hulett, M. D., Parish, C. R.: Histidine-rich glycoprotein: A novel adaptor protein in plasma that modulates the immune, vascular and coagulation systems. Immunol. Cell Biol., $2005,83(2), 106-118$

[6] Jakab, L.: The way of self-defence of the organism: inflammation. [A szervezeti önvédelem módja: a gyulladás.] Orv. Hetil., 2013, 154(32), 1247-1255. [Hungarian]

[7] Jakab, L.: Acute phase reaction of the body. [A szervezeti „acut phasis reactio".] Orv. Hetil., 1993, 134(11), 563-568. [Hungarian]

[8] Klekner, Á., Virga, J., Tóth, J., et al.: The role of extracellular matrix components in the invasion of intracranial malignancies. [Az extracelluláris mátrix komponensek tumorinvázióban betöltött szerepe intrakraniális daganatokban.] Magy. Onkol., 2013, 57(4), 222-231. [Hungarian]

[9] Rosen, S. D.: Ligands for L-selectin: Homing, inflammation, and beyond. Ann. Rev. Immunol., 2004, 22, 129-156.

[10] Fournier, T., Medjoubi-N., N., Porquet, D.: Alpha-1-acid glycoprotein. Biochim. Biophys. Acta, 2000, 1482(1-2), 157-171.

[11] Jakab, L: Physiological and pathophysiological role of adhesion molecules. [Az adhéziós molekulák élettani és kórélettani szerepe.] LAM, 1994, 4(9), 802-818. [Hungarian]

[12] Jakab, L., Kalabay, L.: The acute phase reaction syndrome: the acute phase reactants. Acta Microbiol. Immunol. Hung., 1998, 45(3-4), 409-418.

[13] Gagneux, P., Varki, A.: Evolutionary considerations in relating oligosaccharide diversity to biological function. Glycobiology, $1999,9(8), 747-755$
[14] Jakab, L., Jakab, L., Kalabay, L., et al.: The effect of the alpha 2-HS-glycoprotein on the mitogen-induced lymphoblastic transformation and IL-2 production. Acta Physiol. Hung., 1991, $77(1), 25-31$

[15] Thomas, S., Wolf, S. E., Chinkes, D. L., et al.: Recovery from the hepatic acute phase response in the severely burned and the effects of long-term growth hormone treatment. BURNS, 2004, $30(7), 675-679$.

[16] De Jesus, A. A., Canna, S. W., Liu, Y., et al.: Molecular mechanisms in genetically defined autoinflammatory diseases: disorders of amplified danger signaling. Annu. Rev. Immunol., 2015, 33, 823-874.

[17] Hawkins, P. N., Wotton, R., Pepys, M. B.: Metabolic studies of radioiodinated serum amyloid $\mathrm{P}$ component in normal subjects and patients with systemic amyloidosis. J. Clin. Invest., 1990, $86(6), 1862-1869$

[18] Rieder, F., Schleder, S., Wolf, A., et al.: Serum anti-glycan antibodies predict complicated Crohn's disease behavior: a cohort study. Inflamm. Bowel Dis., 2010, 16(8), 1367-1375.

[19] Rovere, P., Peri, G., Fazzini, F., et al.: The long pentraxin PTX3 binds to apoptotic cells and regulates their clearance by antigenpresenting dendritic cells. Blood, 2000, 96(13), 4300-4306.

[20] Garlanda, C., Bottazzi, B., Bastone, A., et al.: Pentraxins at the crossroads between innate immunity, inflammation, matrix deposition, and female fertility. Annu. Rev. Immunol., 2005, 23, 337-366.

[21] Van Rossum, A. P., Fazzini, F., Limburg, P. C., et al.: The prototypic tissue pentraxin PTX3, in contrast to the short pentraxin serum amyloid $\mathrm{P}$, inhibits phagocytosis of late apoptotic neutrophils by macrophages. Arthritis Rheum., 2004, 50(8), 26672674.

[22] Fries, E., Kaczmarczyk, A.: Inter-alpha-inhibitor, hyaluronan and inflammation. Acta Biochim. Pol., 2003, 50(3), 735-742.

[23] Sander, L. E., Sackett, S. D., Dierssen, U., et al.: Hepatic acutephase proteins control innate immune responses during infection by promoting myeloid-derived suppressor cell function. J. Exper. Med., 2010, 207(7), 1453-1464.

[24] Camozzi, M., Zacchigna, S., Rusnati, M., et al.: Pentraxin 3 inhibits fibroblast growth factor 2-dependent activation of smooth muscle cells in vitro and neointima formation in vivo. Arterioscler. Thromb. Vasc. Biol., 2005, 25(9), 1837-1842.

[25] Varki, A., Angata, T.: Siglecs - the major subfamily of I-type lectins. Glycobiology, 2006, 16(1), 1R-27R

[26] Axford, J.: The impact of glycobiology on medicine. Trends Immunol., 2001, 22(5), 237-239.

[27] Yin, Q., Fu, T. M., Li, J., Wu, H.: Structural biology of innate immunity. Annu. Rev. Immunol., 2015, 33, 393-416.

[28] Crocker, P. R., Varki, A.: Siglecs, sialic acids and innate immunity. Trends Immunol., 2001, 22(6), 337-342.

[29] Latini, R., Maggioni A. P., Peri, G., et al.: Prognostic significance of the long pentraxin PTX3 in acute myocardial infarction. Circulation, 2004, 110(16), 2349-2354.

[30] Bottazzi, B., Doni, A., Garlanda, C., et al.: An integrated view of humoral innate immunity: pentraxins as a paradigm. Annu. Rev. Immunol., 2010, 28, 157-183.

[31] Brubaker, S. W., Bonham, K. S., Zanoni, I., et al.: Innate immune pattern recognition: a cell biological perspective. Annu. Rev. Immunol., 2015, 33, 257-290.

[32] Kemper, C., Atkinson, J. P., Hourcade, D. E.: Properdin: emerging roles of a pattern-recognition molecule. Annu. Rev. Immunol., 2010, 28, 131-155.

[33] Kratz, F., Elsadek, B.: Clinical impact of serum proteins on drug delivery. J. Control. Release, 2012, 161(2), 429-445.

[34] Fernandes, C. L., Ligabue-Braun, R., Verli, H.: Structural glycobiology of human al-acid glycoprotein and its implications for pharmacokinetics and inflammation. Glycobiology, 2015, 25(10), 1125-1133. 
[35] Mibeller, P.: Mechanism of action of selective adhesion inhibitory molecules in inflammarory bowel diseases. [A szelektív adhéziógátló molekulák hatásmechanizmusa gyulladásos bélbetegségekben.] Centr. Eur. J. Gastoenterol. Hepatol., 2015, 1(2), 78-81. [Hungarian]

[36] Azuma, M., Nishioka, Y., Aono, Y., et al.: Role of alphal-acid glycoprotein in therapeutic antifibrotic effects of imatinib with macrolides in mice. Am. J. Respir. Crit. Care Med., 2007, 176(12), 1243-1250.

[37] Buzas, E. I., György, B., Pásztói, M., et al.: Carbohydrate recognition systems in autoimmunity. Autoimmunity, 2007, 39(8), 691-704.

[38] Vaisar, T., Pennathur, S., Green, P. S., et al.: Shotgun proteomics implicates protease inhibition and complement activation in the antiinflammatory properties of HDL. J. Clin. Invest., 2007, $117(3), 746-756$.

[39] Baruah, P., Propato, A., Dumitriu, I. E., et al.: The pattern recognition receptor PTX3 is recruited at the synapse between dying and dendritic cells, and edits the cross-presentation of self, viral, and tumor antigens. Blood, 2006, 107(1), 151-158.

[40] Gabay, C., Kushner, I.: Acute-phase proteins and other systemic responses to inflammation. N. Engl. J. Med., 1999, 340(6), $448-454$.

[41] Cerutti, A., Chen, K., Chorny, A.: Immunoglobulin responses at the mucosal interface. Annu. Rev. Immunol., 2011, 29, 273293.

[42] Arnold, J. N., Wormald, M. R., Sim, R. B., et al.: The impact of glycosylation on the biological function and structure of human immunoglobulins. Annu. Rev. Immunol., 2007, 25, 21-50.
[43] Marshak-Rothstein, A., Rifkin, I. R.: Immunologically active autoantigens: the role of Toll-like receptors in the development of chronic inflammatory disease. Annu. Rev. Immunol., 2007, 25, 419-441.

[44] Bost, F., Diarra-Mehrpour, M., Martin, J. P.: Inter-alpha-trypsin inhibitor proteoglycan family - a group of proteins binding and stabilizing the extracellular matrix. Eur. J. Biochem., 1998, 252(3), 339-346.

[45] Jakab, L., Kalabay, L.: Physiologic and clinical significance of selectins. [A szelektinek élettani, klinikai szerepe.] LAM, 1996, 6(5-6), 284-292. [Hungarian]

[46] Jakab, L.: The liver and the immune system. [A máj és az immunrendszer.] Orv. Hetil., 2015, 156(30), 1203-1213. [Hungarian]

[47] Jakab, L., Pozsonyi, T., Fehér, J., et al.: Cell surface alpha2-macroglobulin of human lymphocytes. In: Peeters, H. (ed.): Protides of the biological fluids. Pergamon Press, Oxford and New York, 1978.

[48] Bettigole, S. E., Glimcher, L. H.: Endoplasmic reticulum stress in immunity. Annu. Rev. Immunol., 2015, 33, 107-138.

[49] Luo, B. H., Carman, C. V., Springer, T. A.: Structural basis of integrin regulation and signaling. Annu. Rev. Immunol., 2007, 25, 619-647.

[50] Rudd, P. M., Elliott, T., Cresswell, P., et al.: Glycosylation and the immune system. Science, 2001, 291(5512), 2370-2376.

(Jakab Lajos dr., Budapest, Kútvölgyi út 4., 1125)

\section{TÉVESZMÉEK AZ ALTERNATIV GYÓGYÁSZATBAN?}

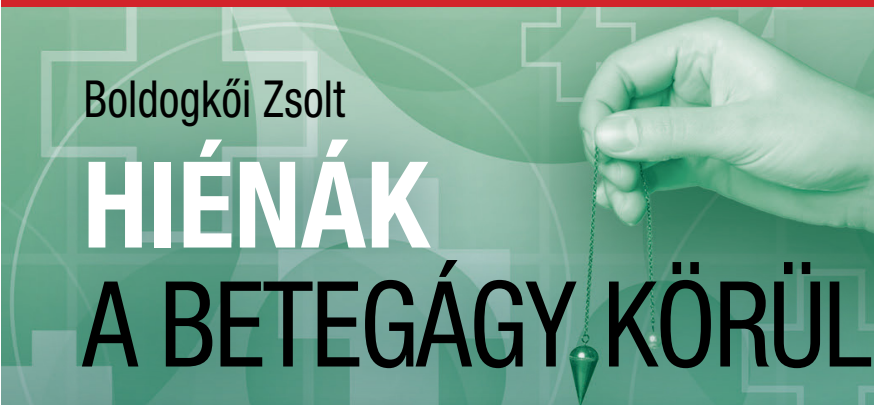

A szerző molekuláris biológusként elszántan küzd az áltudomány és a beteg ember kiszolgáltatott helyzetét kihasználó „kuruzslás” ellen. Könyvében a következő kérdéseket veti fel, állásfoglalása egyértelmü:

- Van-e tudományos alapja az íriszdiagnosztikának, homeopátiának,

lúgosításnak, energiamezőknek?

- Miért csökken a tudományos gyógyitás presztízse, míg az alternatív gyógyítás népszerüsége egyre nő?

- Hogyan mérhető a terápia, a diéta hatása, miért hisznek a betegek csodaszerekben?

- Miért hajlandók sokan komoly összeget áldozni kétséges hatású terápiákra,

szerekre, gyógyhatású készitményekre?

320 oldal, $3400 \mathrm{Ft} \bullet$ világraszóló tudás • www.akademiaikiado.hu
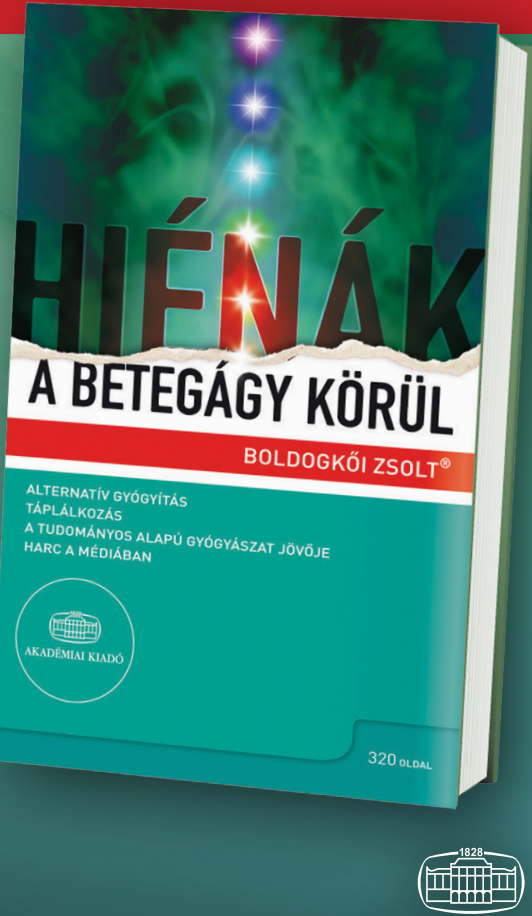

AKADÉMIAI KIADÓ 